American Journal of Applied Sciences 6 (11): 1973-1980, 2009

ISSN 1546-9239

(C) 2009 Science Publications

\title{
The Impact of Air Exchange Effectiveness on Thermal Comfort in an Air-Conditioned Office
}

\author{
Roonak Daghigh and Kamaruzzaman Sopian \\ Solar Energy Research Institute, University Kebangsaan Malaysia, Malaysia
}

\begin{abstract}
Problem statement: Impact of air exchange effectiveness on thermal comfort has not been investigated and, therefore, not well understood .Therefore, the influence of air exchange effectiveness on thermal comfort is investigated in this study. Approach: The main objective of this research is to investigate the thermal comfort level of an air-conditioned office room under 14 windows-door opening arrangements as a function of maximum, minimum and mean Air Exchange Effectiveness (AEE), as has not been inquired into already. The tracer gas decay method has been applied during the experimental procedures to estimate air exchange effectiveness, on the basis of room average and local mean age of air. Simultaneously, thermal comfort variables were measured and through these data, the thermal comforts Fanger's indices (PMV and PPD) were calculated. Staff answered a survey on their sensation of the indoor climate. Results: Results of 60 survey responses to thermal comfort questions in office and indoor air quality are presented. This study has shown that there are relationship between AEE and thermal comfort and three linear regression equations of PMV versus AEE can be derived for this air-conditioned office. Conclusion: Studies on the effect of air exchange effectiveness on thermal comfort in an office have shown that Thermal comfort is influenced by AEE, which go beyond the six factors which have been taken into account in PMV modeling.
\end{abstract}

Key words: Thermal comfort, air exchange effectiveness, tracer gas decay, age of air, objective approach, subjective study

\section{INTRODUCTION}

Indoor air quality and thermal comfort are two important aspects of indoor environmental quality that receive considerable attention ${ }^{[1]}$. The study of thermal comfort is very important because it is correlated not only with occupants' comfort, but also with energy consumption ${ }^{[2]}$. Malaysia is a hot and humid tropical country that has a yearly mean temperature of between $26-27^{\circ} \mathrm{C}^{[3]}$ and has high daytime temperatures of 29 $34^{\circ} \mathrm{C}^{[4]}$ and relative humidity of $70-90 \%$ throughout the year. In recent years, Malaysia's energy consumption has increased and become comparable to larger energy consumers worldwide. With the emergence of energy shortages, climatic changes and sick building syndromes associated with the common usage of airconditioning, natural ventilation can be an appropriate solution for these deteriorating problems ${ }^{[5]}$.

Age of air is an important index to evaluate indoor air quality and air exchange effectiveness greatly influences the indoor air quality, so has become more and more concerned in the past decades In order to assess the air exchange effectiveness and air distribution in room and building, a lot of parameters or indices have been proposed, but the age of air concept is currently used ${ }^{[6]}$. Applied the tracer-gas techniques to the experimental program, concentration decay of $\mathrm{CO}_{2}$ are used to measure age of air and calculate the air exchange effectiveness.

In temperate climates the window is possibly the most common thermal control device in any building. The window opening behavior is not only useful for energy saving, by reducing the need for mechanical cooling, but also provides for a beneficial interaction between the indoor and the outdoor environments ${ }^{[7]}$.

In all studies have been conducted in the hot and humid South East Asian and the surrounding regions since 1930s the proposed neutral temperatures are higher than $24.5^{\circ} \mathrm{C}^{[3,8-11]}$ recommended by ASHRAE Standards $55^{[13]}$. Results of these studies suggest a wider thermal comfort range for these regions that proposed by international standards, i.e., ASHRAE Standard 55, which indicates that Malaysians are acclimatized to much higher environmental temperatures ${ }^{[3]}$.

Corresponding Author: R. Daghigh, Solar Energy Research Institute, University Kebangsaan Malaysia, Malaysia Tel: +60 3-89214596 Fax: +60 3-89214593 
Hence, there is a need to investigate the factors that influence thermal comfort as well as the indoor air quality that can be tolerated by the occupants and determine whether or not there are relationship between them for hot humid climate.

The main objectives of this study are as follows:

- To evaluate the indoor thermal comfort indices of an air-conditioned office through different windows-door opening arrangements and to determine the acceptability with ASHRAE standard 55 and ISO $7730^{[12,13]}$

- To determine and examine air exchange effectiveness in office room through different opening configurations and to determine the acceptability with ASHRAE ${ }^{[14]}$

- To determine whether or not there are relationships between thermal comfort and air exchange effectiveness

\section{MATERIALS AND METHODS}

Experimental work was conducted in an office room at the 5th level of Mechanical Engineering Department office building (block A) Faculty of Engineering at University Putra Malaysia (UPM). The dimension of room was: $4.10,3.80$ and $2.61 \mathrm{~m}$ height. The volume of room was $41 \mathrm{~m}^{3}$ and its surface area was $15.6 \mathrm{~m}^{2}$. The office consists of three interior walls, interior floor and ceiling and one exterior wall with window area. The office is normally used by one person but with a possibility to have meetings around a small round table with up to four people taking part.

The Room was equipped with an independent airconditioner and was fitted with one window area and one door. The dimension of the window area was: 2.11 by 2.45 . Two bottom hung windows which were in window area with the dimensions Width $\times$ Height $=$ $0.47 \times 1.1 \mathrm{~m}$ were mounted $60 \mathrm{~cm}$ below the ceiling.

For these windows and one door at office room, 14 different opening arrangements were carried out, as shown in Table 1.

Theoretical background of age of air: The local mean age of air is an index used to quantify ventilation effectiveness and to visualise air flow patterns in a ventilation system. The age-of-air is the mean time that it takes for a particle (e.g., a molecule) to travel from an inlet point, such as the outdoor air intake, to the measurement point ${ }^{[6,15,16]}$. When the characteristics of the air distribution system are varied, a longer age of air suggests poorer outside air delivery compared to a shortage of air for the same location. The age of air has units of time, usually in seconds or minutes ${ }^{[14]}$. Roomaverage age-of-air is a value which quantifies the performance of a ventilation system. This number takes into account both the amount of ventilation air supplied to the room and the efficiency with witch it is distributed around the room. Room-average age-of-air is measured in the extract air duct ${ }^{[16]}$. This parameter is used to assess ventilation effectiveness ${ }^{[17]}$.

Using the tracer-gas concentration-decay method the room-average age-of-air, $\langle\tau\rangle$, is given by ${ }^{[16]}$ :

$$
\begin{aligned}
& \langle\tau\rangle= \\
& \frac{1 / 8 \times \mathrm{C}_{0} \times \Delta \tau+1 / 2 \times \mathrm{C}_{\mathrm{M}} \times \Delta \tau \times \tau_{\mathrm{M}}+\sum_{\mathrm{j}=1}^{\mathrm{M}-1} \mathrm{C}_{\mathrm{j}} \tau \tau_{\mathrm{j}} \Delta \tau+\frac{\mathrm{C}_{\mathrm{M}}}{\lambda_{\text {exp }}}\left(\tau_{\mathrm{M}}+\frac{1}{\lambda_{\text {exp }}}\right)}{\frac{1}{2} \times\left(\mathrm{C}_{0}+\mathrm{C}_{\mathrm{M}}\right) \times \Delta \tau+\sum_{\mathrm{j}=1}^{\mathrm{M}-1} \mathrm{C}_{\mathrm{j}} \Delta \tau+\frac{\mathrm{C}_{\mathrm{M}}}{\lambda_{\text {exp }}}}
\end{aligned}
$$

Where:

$\mathrm{C}_{\mathrm{j}}=$ Concentration Measurement $\mathrm{j}$

$\mathrm{C}_{\mathrm{M}}=$ Final Concentration Measured

$\mathrm{M}=$ Number of measurements

$\Delta \tau=$ Sampling interval

$\lambda_{\exp }=$ Slope in the exponential decay region

$\mathrm{t}_{\mathrm{j}} \quad=$ Time of measurement $\mathrm{j}$

$\mathrm{t}_{\mathrm{M}}=$ Total measuring time, $\mathrm{t}_{\mathrm{M}}=\mathrm{M} \times \Delta \tau$

Table 1: Variable conditions of windows-door arrangements for airconditioned office room

\begin{tabular}{lll}
\hline $\begin{array}{l}\text { Door } \\
\text { position }\end{array}$ & Windows positions & Code \\
\hline Closed & Two windows closed & B \\
& Two windows opened & X \\
& Windows No.1 and No.2 half opened & Y \\
& Window No.1 fully opened, window No.2 closed & $\mathrm{I}$ \\
& Window No.1 half opened, window No.2 closed & J \\
& Window No.2 fully opened, window No.1 closed & K \\
& Window No.2 half opened, window No.1 closed & L \\
Opened & Two Windows Closed & D \\
& Two Windows Opened & AB \\
& Windows No.1 and No.2 half opened & AC1 \\
& Window No.1 fully opened, windows No.2 closed & Q \\
& Window No.1 half opened, window No.2 closed & R \\
& Window No.2 fully opened, window No.1 closed & S \\
& Window No.2 half opened, window No.1 closed & T \\
\hline
\end{tabular}

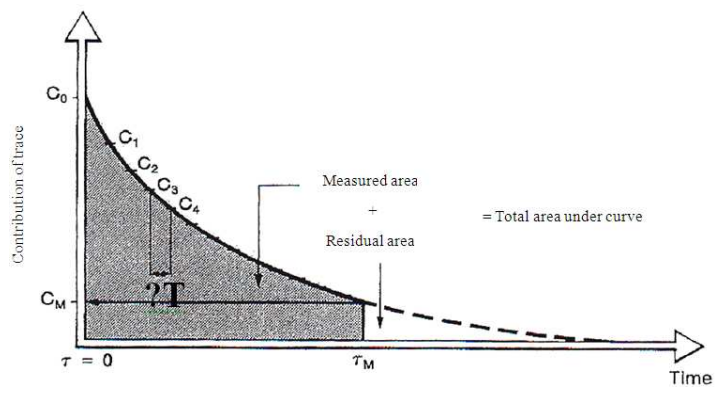

Fig. 1: Distribution of the tracer-gas concentration as a function of time ${ }^{[16]}$ 
Am. J. Applied Sci., 6 (11): 1973-1980, 2009

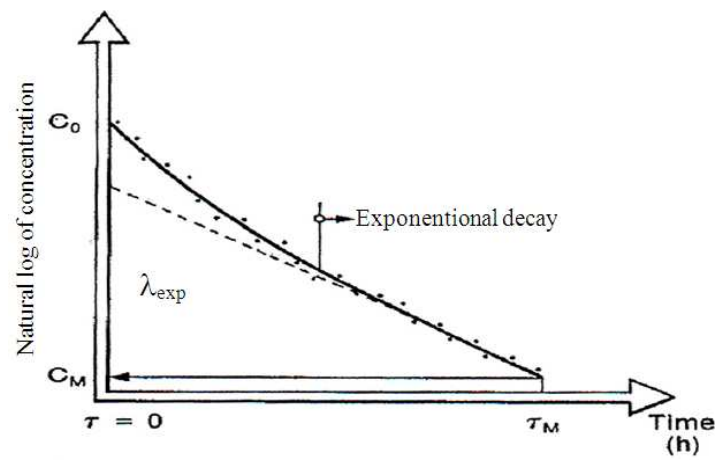

Fig. 2: Logarithmic plot of decay rate data ${ }^{[16]}$

Table 2: Age of air measurement Eq. ${ }^{[16]}$

\begin{tabular}{lll}
\hline \multirow{2}{*}{$\begin{array}{l}\text { Tracer-gas measurement } \\
\text { method }\end{array}$} & $\begin{array}{l}\text { Local mean } \\
\text { age-of-air } \\
\text { (Arbitrary } \\
\text { measurement point) }\end{array}$ & $\begin{array}{l}\text { Room average } \\
\text { age- of-air } \\
\text { (Measured in } \\
\text { exhaust) }\end{array}$ \\
\hline \multirow{2}{*}{ Concentration decay method } & $\frac{\int_{0}^{\infty} \mathrm{C}(\tau) \mathrm{d} \tau}{\mathrm{C}(0)}$ & $\frac{\int_{0}^{\infty} \tau \times \mathrm{C}_{\mathrm{exh}}(\tau) \mathrm{d} \tau}{\int_{0}^{\infty} \mathrm{C}_{\mathrm{exh}}(\tau) \mathrm{d} \tau}$ \\
\hline
\end{tabular}

Typical plots of the tracer-gas concentration as a function of time and natural logarithm of tracer-gas concentration against time are shown in the Fig. 1 and 2.

In practice the measurements are stopped when the concentration begins to decay exponentially, since the residual area under the curve can be calculated with good accuracy using a simple equation. If the point at which the concentration change has been studied is in the extract air duct then the room-average age-of-air can be calculated. We can also calculate the air change rate for the room as a whole (local-mean age-of-air in extract) ${ }^{-1}$ and see whether or not there are areas of stagnant air in the room. By measuring the local-mean age-of-air at different points in room areas of stagnant air can be located. Age of air measurement equations are presented in Table 2 .

Objective approach: The thermal comfort level of the indoor environment is measured using a measuring physical quantities instrument (BABUCA) that was able to measure air velocity, relative humidity, dry bulb temperature and mean radiant temperature.

All measurements were taken at a height of $1.1 \mathrm{~m}$ above the floor, which represents the height of the occupant at seated level. The instrument was placed at work plane level in the rooms at $1.5 \mathrm{~m}$ from the window. These measurements were carried out at one point at the middle of office. The samples were recorded every one minute interval.
In this study, the metabolic rate is set to be $1.2 \mathrm{~m}^{[13]}$ which is sedentary activities (office, dwelling, school, laboratory) whereas the Clo-value (thermal resistance) is set to be 0.5 where the males were wearing underpants, shirt with short sleeves, light trousers, light socks and shoes. The females were wearing 'baju kurong' which is cotton or silk with light cotton undergarments and a lightweight scarf.

The age of air concept was used to evaluate the air exchange effectiveness. The concentration-decay of the tracer-gas was used to determine age of air and air exchange effectiveness in the office room. To measure the mean age of air and air exchange effectiveness the tracer gas $\left(\mathrm{CO}_{2}\right)$ was injected into the test room and this was followed by a mixing period of $15 \mathrm{~min}^{[18,19]}$ to establish a uniform concentration in the air space during which desk fan was used. After an acceptably uniform initial tracer gas concentration was attained, the tracer gas decay occurred. IAQ meter located beside the BABUCA and two sampling location inside the room (the middle of the room) and one sampling location at the system exhaust was considered. The sampling location inside the room was at a height of $1.1 \mathrm{~m}$ above the floor. The tracer gas decay protocol was as follows: at the beginning windows and door were closed, whenever tracer gas decay started one of 14 different opening arrangements was carried out. The precision of the test method was determined by recharging the room with $\mathrm{CO}_{2}$, several times for each condition and reanalyzing the decay, at the same time, also thermal comfort parameters measurements were repeated.

\section{Calibration:}

- The BABUCA and IAQ meters were calibrated before experimental work

- Second measurement of room temperature, humidity and air velocity was taken using thermocouple wires, temperature and humidity tester and air velocity meter

- Before using the thermocouple wires calibration was done

- Mean coefficient of variation of these tests in comparison to BABUCA and IAQ meters were (0.96-1)

- The precision of the concentration decay method was determined by recharging the room with $\mathrm{CO}_{2}$ and reanalyzing the decay. The mean coefficient of variation of several duplicated tests for the slope of line was $2 \%$

Subjective measurements: Subjective thermal comfort data were recorded using a questionnaire, the 
Am. J. Applied Sci., 6 (11): 1973-1980, 2009

questionnaire developed for this survey was divided into four main sections: Demographic information, current status of thermal comfort, use of controls, thermal sensation and preferences and current clothing garment.

A sample size of 60 subjects, all staffs, took part in the survey. The staffs were given one hour to answer the questionnaire and to return it. The dominant gender distribution sampled was male $(66.6 \%)$ The total response rate was $100 \%$. Prior to the survey, the subjects would have been seated at their chairs for approximately $30 \mathrm{~min}^{[20]}$, with mostly sedentary activities. Sufficient time for body precondition in each survey was necessary to maintain respondent's Metabolic rate $(\mathrm{M})$ at the same level throughout the study which was estimated to be equal to $1.2 \mathrm{~m}$.

During the experimental work and conducting survey for all of 14 conditions, air conditioner was on.

\section{RESULTS AND DISCUSSION}

Evaluation of age of air and local air exchange effectiveness: Various age of air $(\tau)$ and local air exchange effectiveness $\left(\varepsilon_{\mathrm{L}}\right)$ are computed and tabulated in Table 3. A sample of variation of local tracer gas concentration $\mathrm{Vs}$ time for condition $\mathrm{AC} 1$ is shown in Fig. 3.

When there is a uniform distribution of air over the office air-space, $\varepsilon_{\mathrm{L}}=1$. However, when there is a nonuniform distribution of air over the office air-space or in another word, some stagnant zones within office airspace, values of $\varepsilon_{\mathrm{L}}$ are significantly less than 1 . A value less than 1.0 shows less than perfect mixing with some degree of stagnation. A value of $\varepsilon_{\mathrm{L}}>1$ suggests that a degree of plug or displacement flow is ${ }^{[14]}$.

The local air exchange effectiveness in the middle of office room was found to be in the range 0.91-1.03. These imply that there is no short-circuiting of ventilation air under 14 conditions in mechanically ventilated office present in accordance with $^{[14,21]}$. The local air exchange effectiveness indicated a reasonably perfect mixed air in the middle of room in all conditions. Opening windows and door have improved air exchange effectiveness ${ }^{[22]}$. The air age at the windows-door opening conditions is young. This is because fresh air is drawn into the office. In general there are improvements in air exchange effectiveness in windows-door open cases.

The AEE values of 0.91-1.03 indicated in Table 3 are comparable to similar studies ${ }^{[23,24]}$ in office buildings in USA and Singapore. Nine office buildings were studied in the $\mathrm{USA}^{[23]}$, results indicated AEE values were in the range of 0.8-1.4. A seven-storey office building was studied in Singapore and air exchange effectiveness values were 096-1.04 ${ }^{[24]}$.
Table 3: Measurements of age of air and air exchange effectiveness for office

\begin{tabular}{lccl}
\hline Code & Exhaust, $\tau_{\mathrm{E}}(\mathrm{s}) \mathrm{A}$ & Local, $\tau_{\mathrm{L}}(\mathrm{s}) \mathrm{B}$ & Local $\varepsilon_{\mathrm{L}} \mathrm{A} / \mathrm{B}$ \\
\hline $\mathrm{B}$ & 2184 & 2400 & 0.91 \\
$\mathrm{X}$ & 600 & 600 & 1.00 \\
$\mathrm{Y}$ & 1247 & 1260 & 0.99 \\
$\mathrm{I}$ & 1339 & 1380 & 0.97 \\
$\mathrm{~J}$ & 2009 & 2160 & 0.93 \\
$\mathrm{~K}$ & 1500 & 1500 & 1.00 \\
$\mathrm{~L}$ & 2098 & 2280 & 0.92 \\
$\mathrm{D}$ & 1653 & 1740 & 0.95 \\
$\mathrm{AB}$ & 267 & 264 & 1.01 \\
$\mathrm{AC} 1$ & 1298 & 1260 & 1.03 \\
$\mathrm{Q}$ & 989 & 960 & 1.03 \\
$\mathrm{R}$ & 1530 & 1500 & 1.02 \\
$\mathrm{~S}$ & 1224 & 1200 & 1.02 \\
$\mathrm{~T}$ & 1394 & 1380 & 1.01 \\
\hline
\end{tabular}

Table 4: Distribution of PMV and PPD for 14 windows-door opening

\begin{tabular}{|c|c|c|}
\hline Code & PMV & PPD (\%) \\
\hline $\bar{B}$ & $(-2.5)-(-2.1)$ & $77.5-87.5$ \\
\hline $\mathrm{X}$ & $0.7-1.1$ & $16-30$ \\
\hline Y & $(-0.1)-(-1)$ & $6-25$ \\
\hline I & $(-0.8)-(-1.1)$ & $19-30$ \\
\hline $\mathrm{J}$ & $(-1.7)-(-2.1)$ & $60-77.5$ \\
\hline K & $(-0.9)-(0.8)$ & $19-22$ \\
\hline $\mathrm{L}$ & $(-1.6)-(-2)$ & $55-75$ \\
\hline D & $(-1.3)-(-1.5)$ & $40-50$ \\
\hline $\mathrm{AB}$ & $0.9-1.3$ & $22-40$ \\
\hline ACI & $0.3-0.8$ & $8-19$ \\
\hline $\mathrm{Q}$ & $0.5-0.9$ & $10-22$ \\
\hline $\mathrm{R}$ & $(-0.5)-(0.8)$ & $10-19$ \\
\hline $\mathrm{S}$ & $0.3-1$ & $8-25$ \\
\hline $\mathrm{T}$ & $(-0.4)-(0.6)$ & $9-13$ \\
\hline
\end{tabular}

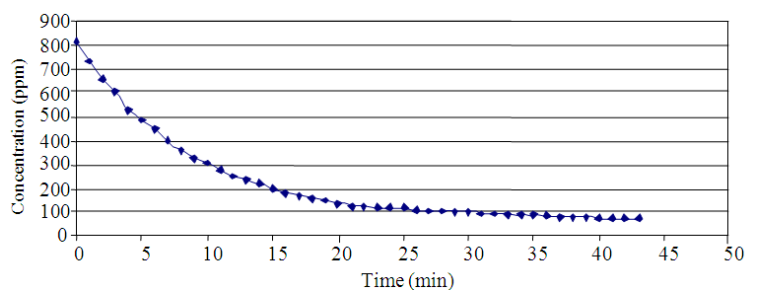

Fig. 3: Variation of local tracer gas concentration vs. time for control condition (AC1)

From the measurement results, relatively high airexchange effectiveness had been obtained in airconditioned office under 14 conditions. This was due to the adequate supply of fresh air and the mechanical air diffusion system had good performance in exchanging the old air with fresh air.

Evaluation of the thermal comfort: Distributions of PMV and PPD for fourteen conditions are listed in Table 4. A sample of the graph of Predicted Percentage of Dissatisfied (PPD) as a Function of Predicted Mean Vote (PMV) for Air-Conditioned Office is shown in Fig. 4. 


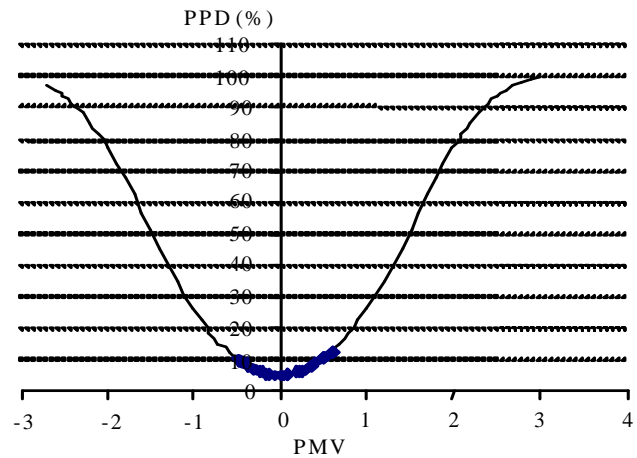

Fig. 4: Condition T-Predicted Percentage of Dissatisfied (PPD) as a function of Predicted Mean Vote (PMV). (ISO 7730)

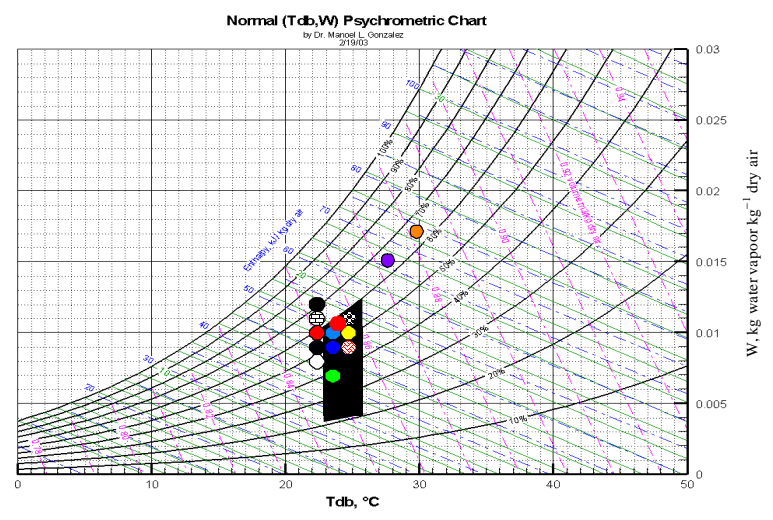

Fig. 5: Thermal comfort range based on psychometric chart-ASHRAE 55-14 windows-door opening arrangements

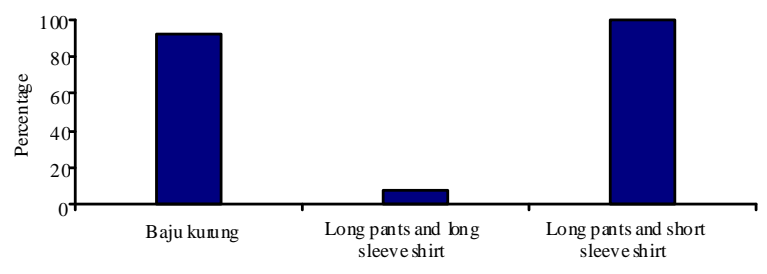

Fig. 6: Type of clothing worn

Table 5: Demographic data of respondents

\begin{tabular}{llllll}
\hline & Age (years) & & & \\
& - & & & \\
& Below 20 & $20-30$ & $30-40$ & Above 40 & Total \\
\hline Male & - & 4 & 12 & 4 & 20 \\
Female & - & 20 & 15 & 5 & 40 \\
Total & - & 24 & 27 & 9 & 60 \\
\hline
\end{tabular}

Data analysis based on simulation with reference to the ISO 7730 and ASHRAE 55-92: From the analysis using InfoGap and Microsoft Excel, the microclimate indices calculation in Moderate Environment shows that the ranges of Predicted Mean Vote (PMV) for AirConditioned office for 14 conditions was between -2.51.3 as shown in Table 4. The comfort range was taken to be the conditions when the PMV has the values between -1 and +1 . Results showed that the office is within the comfort range during working hours for most of conditions in office.

The ASHRAE Standard 55-1992 states that the comfort zone for summer conditions in cold countries air temperature to be between $23-26^{\circ} \mathrm{C}$ and relative humidity between $20-60 \%$. The office is within the comfort range based on ASHRAE Standard 55-1992 during working hours under these conditions (Fig. 5): $\mathrm{Y}, \mathrm{R}, \mathrm{T}, \mathrm{AC} 1, \mathrm{~S}, \mathrm{~K}$ and $\mathrm{Q}$.

Subjective assessment: Assessment of thermal comfort in the office was based on responses to a questionnaire survey, which was administered simultaneously with the physical measurements in each condition. A total of 60 respondents participated in the survey for each condition, out of which 40 were female and 20 were male. They were from different offices. The basic demographic data of the respondents are summarized in Table 5.

Type of clothing worn: Figure 6 shows the type of clothing of staff in the office during working hours. $90 \%$ of female and $100 \%$ of male were wearing baju kurong and long pants and short sleeve shirt. In respect to afore mention, equivalent Clo-value is set to be 0.5 .

Analysis of votes on ASHRAE scale: From the relative frequency of votes in each category, it can be seen that in the most conditions the thermal vote centered around -2 (cool) and -1 (slightly cool).

Adaptive behavior: Of all available controls, airconditioner, windows and clothing have the biggest effects on indoor climate in mechanically ventilated office in most of conditions. On an average, $100 \%$ of the total responses in all of conditions reported turning off air-conditioner when the office was cold and 100\% turning it on again when office was warm. Average, 92.8 and $53.3 \%$ of the total responses reported open windows, when office was cold or when it was warm because of switching off air-conditioner, respectively. The third option was taking garment off. Figure 7 shows the list of adaptive actions commonly occurred in office for condition B as a sample graph and their percentage of people who choose to employ them for this condition. 


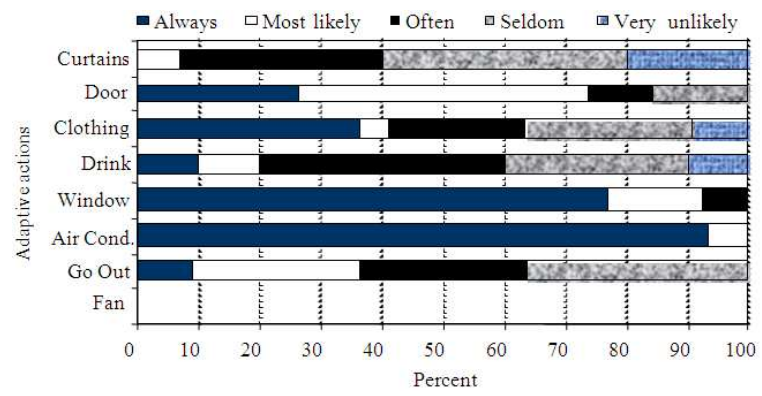

Fig. 7: Adaptive behavior for condition B

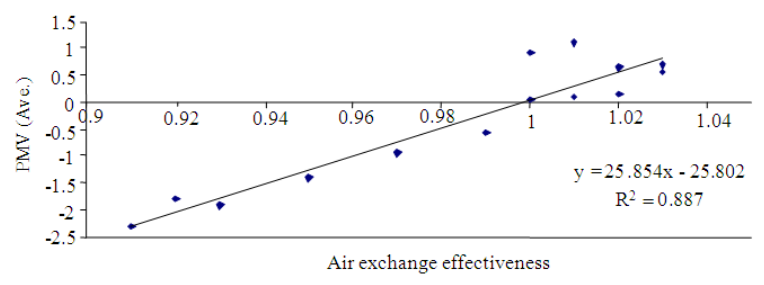

Fig. 8: Predicted mean vote (Ave.) Vs air exchange effectiveness

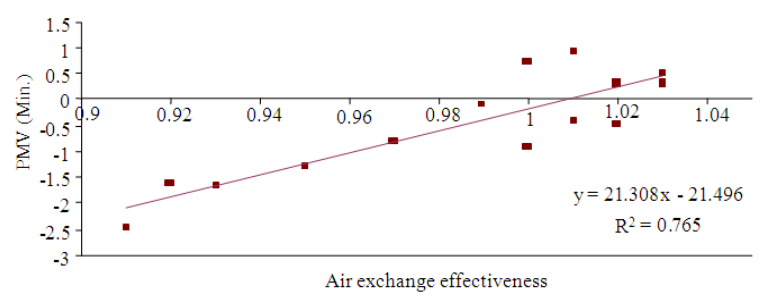

Fig. 9: Predicted mean vote (Min.) Vs air exchange effectiveness

Assessment of air quality: Result obtained from the evaluation of age of air and air exchange effectiveness in office showed that there was uniformity in air distribution in office room in all conditions; this means that the local air exchange electiveness indicated a reasonably perfect mixed air in all conditions. This was due to the adequate supply of fresh air and the mechanical air diffusion system had good performance in exchanging the old air with fresh air and opening windows and door improved air exchange effectiveness. The windows and doors open bear correlation with improving airflow pattern in office and this is in connection to other researches ${ }^{[24,25]}$.

The thermal comfort values obtained using Fanger's Equations for office showed that the office was in the ISO 7730 comfort range for most of conditions.

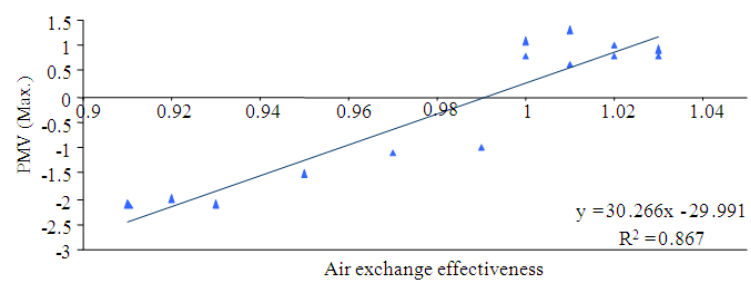

Fig. 10: Predicted mean vote (Max.) Vs air exchange effectiveness

Table 6: PMV equations vs. AEE for air-conditioned office

\begin{tabular}{lll}
\hline Equation No. & Equation & $\mathrm{R}^{2}$ \\
\hline 1 & $\mathrm{PMV}($ Ave. $)=25.854 \varepsilon_{\mathrm{L}}-25.802$ & 0.887 \\
2 & $\mathrm{PMV}($ Min. $)=21.308 \varepsilon_{\mathrm{L}}-21.496$ & 0.765 \\
3 & $\mathrm{PMV}($ Max. $)=30.266 \varepsilon_{\mathrm{L}}-29.991$ & 0.867 \\
\hline
\end{tabular}

Results obtained from the survey showed that in the most conditions the thermal vote centered around -2 (cool) and -1 (slightly cool) and a large percentage of staff voting at the warmer categories for founding their thermal state acceptable. Results of these study suggest a wider thermal comfort range for Malaysian than that proposed by international standards, i.e., ASHRAE Standard 55, which indicates that Malaysian are acclimatized to much higher environmental temperatures. The result of this study is also in accordance to other studies in Malaysia and surrounding regions. Therefore adopting the international standards for interior comfort conditions for the Malaysian hot and humid tropical climate may lead to overcooling and energy waste. The result of this study is also in line with the current revisions to ASHRAE standard 55 that will include a new Adaptive Comfort Standard (ACS) that allows warmer indoor temperatures for naturally ventilated buildings in warmer climate zones.

ASHRAE Standard 62 defines acceptable air quality as conditions in which more than $80 \%$ of people do not express dissatisfaction. Analysis of database show that most of staff in majority of condition meets the intent of this standard and the information obtained from the measurements and questionnaires show that office room has good air quality.

Effect of Predicted Mean Vote (PMV) on Air Exchange Effectiveness (AEE):

Simple linear regression for 14 windows-door opening arrangements: The relationship between air exchange effectiveness and the predicted mean vote are shown in Fig. 8-10. The graphs are represented by simple linear regression technique. Figure 8-10 show 
how the PMV varies with the air exchange effectiveness. The linear regression equations are described by Eq. 1-3. Based on the regression analysis with confidence limits of $95 \%$, three simple correlation equations can be shown in Table 6. The correlation coefficients $\mathrm{R}^{2}$ are $88.7,76.5$ and $86.7 \%$ and there are high relationship between air exchange effectiveness and predicted mean vote.

Analysis of variance (ANOVA) for PMV and AEE: A hypothesis was developed to determine whether there is a relationship between PMV and Air Exchange Effectiveness (AEE). Therefore three ANOVA tests were carried on to determine whether there is any significant correlation between AEE and PMV (Ave.), PMV (Min.) and PMV (Min.).The hypotheses are:

- H0: If $p>0.05$ then there is not relationship between PMV and AEE

- H0: If $p<0.05$ then there is high relationship between PMV and AEE

P-values for ANOVA test are $5 \times 10^{-07}, 4.289 \times 10^{-05}$ and $1.323 \times 10^{-06}$ and for t-test are $5 \times 10^{-07}, 4.3 \times 10^{-05}$ and $1.3 \times 10^{-06}$ mean that hypotheses are accepted so their significance levels are less than 0.05 which means that the correlation is statistically significant.

\section{CONCLUSION}

- The comfort range was determined to be the conditions when the PMV has the values between 1 and +1 , based on ISO 7730. Thermal Comfort study of the office showed that in most of conditions, PMV and PPD indices for office is within these ranges

- Thermal Comfort study of the office showed that in most of conditions, the office had thermal conditions falling within the comfort zone of ASHRAE standard 55

- In the case of air exchange effectiveness, it is observed that the AEE values are usually close to one implying no serious problems of short circuiting of ventilation air in this office and that the ventilation air is well mixed and in most variable conditions of windows-door arrangements were in accordance with recommended value by ASHRAE Fundamental Handbook

- The information obtained from questionnaires show that the office has good air quality in most conditions
- Results of subjective approach suggest a wider thermal comfort range for Malaysian than that proposed by international standards, i.e., ASHRAE Standard 55, which indicates that Malaysian are acclimatized to much higher environmental temperatures

- Studies on the effect of air exchange effectiveness on thermal comfort in an office have shown that Thermal comfort is influenced by AEE (High $\mathrm{R}^{2}$ and $\mathrm{P}$ values less than 0.05 for ANOVA and t-test) which go beyond the six factors which have been taken into account in PMV modeling. It is believed that AEE have contributed in some positive ways to the higher level of thermal comfort

- In this study it has been observed that by approaching the air exchange effectiveness to 1 (uniform distribution of air) PMV average, minimum and maximum values nearly closed to ISO7730 comfort range $(-1$ to +1$)$ in office. For some conditions lower conformity compare to another cases was obtained which could be related to the high dependency of PMV to the fundamental parameters of dry bulb temperature, relative humidity, air velocity and mean radiant temperature and could be due to this fact that inside and outside relative humidities, dry bulb and mean radiant temperatures in that conditions are relatively high

\section{REFERENCES}

1. Huizenga, C., S. Abbaszadeh, L. Zagreus and E. Arens, 2006. Air quality and thermal comfort in office buildings: Results of a large indoor environmental quality survey. Proceedings of Healthy Buildings, June 4-8, University of Porto, Lisbon, pp: 393-397.

2. Ye, X.J., Z.P. Zhu, Z.W. Lian, H.M. Liu, C.Z. Li and Y.M. Liu, 2006. Field study of a thermal environment and adaptive model in Shanghai. Indoor Air, 16: 320-326. DOI: 10.1111/j.16000668.2006.00434.x

3. Sabarinah Ahmad, S.H., 2005. Thermal comfort and building performance of naturally ventilated apartment building in the Kelang valley: A simulation study. Proceedings of the Energy in Buildings (Sustainable Symbiosis) Seminar, May 10-11, Subang Jaya, Malaysia, pp: 115-132.

4. Rahman, S.A. and K.S. Kannan, 1997. Air flow and thermal comfort simulation studies of wind ventilated classrooms in Malaysia. Renew. Energy, 8: 264-267.

http://cat.inist.fr/?aModele=afficheN\&cpsidt=3165455 
5. Liping, W. and W.N. Hien, 2007. The impacts of ventilation strategies and facade on indoor thermal environment for naturally ventilated residential buildings in Singapore. Build. Environ., 42: 4006-4015. DOI: 10.1016/j.buildenv.2006.06.027

6. Li, X., D. Li, X. Yang and J. Yang, 2006. Total air age: An extension of the air age concept. Build. Environ., 38: 1263-1269. DOI: 10.1016/S03601323(03)00133-1

7. Rijal, H.B., P. Tuohy, M.A. Humphreys, J.F. Nicol, A. Samuel and J. Clarke, 2007. Using results from field surveys to predict the effect of open windows on thermal comfort and energy use in buildings. Energy Build., 39: 823-836. DOI: 10.1016/j.enbuild.2007.02.003

8. De Dear, R.J., K.G. Leow and S.C. Foo, 1991. Thermal comfort in the humid tropics: Field experiment in air-conditioned and naturally ventilated buildings in Singapore. Int. J. Biometeorol., 34: 259-265. DOI: 10.1007/BF01041840

9. Busch, J.F., 1990. Thermal responses to the Thai office environment. ASHRAE Trans., 96: 859-872. http://www.inive.org/Ibase_search/search-detailairbase-001.asp?ID=4773

10. Abdul Rahman, S. and K.S. Kannan, 1997. A study of thermal comfort in naturally ventilated classrooms: Towards new indoor temperature standards. Proceeding of the Asia Pacific Conference on the Built Environment, Nov. 3-6, Kuala Lumpur, Malaysia.

11. Zain-Ahmad, A., A.A.M. Sayigh, P.N. Surendran and M.Y. Othman, 1998. The bioclimatic design approach to low-energy buildings in the Klang valley Malaysia. Renew. Energy, 15: 437-440. http://cat.inist.fr/?aModele $=$ afficheN\&cpsidt $=1629$ 080

12. ASHRAE., 1992. Thermal environmental conditions for human occupancy. Standard 551992. American Society of Heating, Refrigerating, and Air-Conditioning Engineers, Atlanta, USA.

13. ISO 7730, 1994. Moderate thermal environmentsdetermination of the PMV and PPD indices and specifications for thermal comfort. International Organization for Standardization.

http://www.iso.org/iso/catalogue_detail.htm?csnum ber $=14567$

14. ASHRAE., 2005. American society of heating, refrigerating and air-conditioning engineers, Atlanta, USA. http://aec.ihs.com/collections/ashrae/index.htm
15. Federspiel, C.C., 1999. Air-change effectiveness: Theory and calculation methods. Indoor Air, 9: 47-56. http://www.ncbi.nlm.nih.gov/pubmed/10195276

16. Grieve, P.W., 1989. Measuring Ventilation Using Tracer Gases. In: Technical Documentation, Bruel and Kjaer (Eds.). Naerum, Denmark.

17. Buggenhout, S.V., T.Z. Desta, A.V. Brecht, E. Vranken and S. Quanten et al., 2006. Data-based mechanistic modeling approach to determine the age of air in a ventilated space. Build. Environ., 41: 557-567. DOI: 10.1016/j.buildenv.2005.02.029

18. Cheong, K.W. and K.Y. Chong, 2001. Development and application of an indoor air quality audit to air-conditioned building in Singapore. Build. Environ., 36: 181-188. DOI: 10.1016/S0360-1323(99)00064-5

19. Cheong, K.W.D. and H.Y.T. Lau, 2003. Development and application of an indoor air quality audit to an air-conditioned tertiary institutional building in the tropics. Build. Environ., 38: 605-616. DOI: 10.1016/S03601323(02)00183-X

20. Feriadi, H. and N.H. Wong, 2004. Thermal comfort for naturally ventilated houses in Indonesia. Energy Build., 36: 614-626. 10.1016/j.enbuild.2004.01.011

21. Rock, B.A., M.J. Brandemuehl and R.S. Anderson, 1995. Toward a simplified design method for determining the air change effectiveness. ASHRAE Trans., 101: 217-227. http://www.nrel.gov/docs/gen/fy01/21021.pdf

22. Lin, Z., T.T. Chow and C.F. Tsang, 2007. Effect of door opening on the performance of displacement ventilation in a typical office building. Build. Environ., 42: 1335-1347. DOI: 10.1016/j.buildenv.2005.11.005

23. Fisk, W.J. and D. Faulkner, 1993. Air exchange effectiveness in office buildings: Measurement techniques and results. Proceeding of the International Symposium on Room Air Convection and Ventilation Effectiveness, July 22-24, ASHRAE, Tokyo, pp: 213-223.

24. Sekhar, S.C., K.W. Tham and D. Cheong, 2002. Ventilation characteristics of an air-conditioned office building in Singapore. Build. Environ., 37: 241-255. DOI: 10.1016/S0360-1323(01)00027-0

25. Chao, C.Y., M.P. Wan and A.K. Law, 2004. Ventilation performance measurement using constant concentration dosing strategy. Build. Environ., $\quad 39$ : $1277-1288 . \quad$ DOI: 10.1016/j.buildenv.2004.03.012 